\title{
Retraction Note: Light Harvesting-like Protein 3 Interacts with Phytoene Synthase and Is Necessary for Carotenoid and Chlorophyll Biosynthesis in Rice
}

Feng Yang ${ }^{1,2+}$, Das Debatosh ${ }^{2+}$, Tao Song ${ }^{1,2^{*}}$ and Jian-hua Zhang ${ }^{2,3^{*}}$

Retraction Note: Rice 14, 32 (2021)

https://doi.org/10.1186/s12284-021-00474-z

The authors have retracted this article. Following publication, errors were discovered in Figure 1, Figure 5 and Table 1 . The authors have stated that the phenotypic characterization of oslil 3 mutant still needs further experiments to analyze the intermediate metabolites in carotene biosynthesis such as the contents of alfacarotene and beta-carotene, and that the analysis of oslil3 mutant is not precisely described. In addition, the authors have stated that they need to further analyze the protein accumulation levels of OsPSYs in the mutant as compared with the WT via the PSYs specific antibodies to more accurately validate the interaction between LIL3 and PSYs. The authors intend to resubmit a revised manuscript. All authors agree with this retraction.

\section{Author details}

'Co-Innovation Center for Sustainable Forestry in Southern China, College of Biology and the Environment, Nanjing Forestry University, Nanjing 210037, China. ${ }^{2}$ Shenzhen Research Institute, The Chinese University of Hong Kong, Shenzhen 518057, Guangdong, China. ${ }^{3}$ Department of Biology, Hong Kong Baptist University and State Key Laboratory of Agrobiotechnology, The Chinese University of Hong Kong, Shatin, Hong Kong, China.

Published online: 12 May 2021

\footnotetext{
The original article can be found online at https://doi.org/10.1186/s12284021-00474-z.

*Correspondence: tsong@cuhkri.org.cn; jzhang@hkbu.edu.hk

${ }^{\dagger}$ Feng Yang and Das Debatosh contributed equally to this work.

${ }^{1}$ Co-Innovation Center for Sustainable Forestry in Southern China, College of Biology and the Environment, Nanjing Forestry University, Nanjing 210037,

China

${ }^{2}$ Shenzhen Research Institute, The Chinese University of Hong Kong,

Shenzhen 518057, Guangdong, China

Full list of author information is available at the end of the article
}

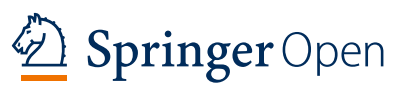

(-) The Author(s). 2021 Open Access This article is licensed under a Creative Commons Attribution 4.0 International License, which permits use, sharing, adaptation, distribution and reproduction in any medium or format, as long as you give appropriate credit to the original author(s) and the source, provide a link to the Creative Commons licence, and indicate if changes were made. The images or other third party material in this article are included in the article's Creative Commons licence, unless indicated otherwise in a credit line to the material. If material is not included in the article's Creative Commons licence and your intended use is not permitted by statutory regulation or exceeds the permitted use, you will need to obtain permission directly from the copyright holder. To view a copy of this licence, visit http://creativecommons.org/licenses/by/4.0/. 